\title{
Subseafloor basalts as fungal habitats
}

\author{
M. Ivarsson \\ Swedish Museum of Natural History, Department of Palaeozoology and Nordic Center for Earth Evolution (NordCEE), \\ Box 50007, Stockholm, Sweden \\ Correspondence to: M. Ivarsson (magnus.ivarsson@nrm.se)
}

Received: 15 February 2012 - Published in Biogeosciences Discuss.: 29 February 2012

Revised: 21 August 2012 - Accepted: 27 August 2012 - Published: 18 September 2012

\begin{abstract}
The oceanic crust is believed to host the largest potential habitat for microbial life on Earth, yet, still we lack substantial information about the abundance, diversity, and consequence of its biosphere. The last two decades have involved major research accomplishments within this field and a change in view of the ocean crust and its potential to harbour life. Here fossilised fungal colonies in subseafloor basalts are reported from three different seamounts in the Pacific Ocean. The fungal colonies consist of various characteristic structures interpreted as fungal hyphae, fruit bodies and spores. The fungal hyphae are well preserved with morphological characteristics such as hyphal walls, septa, thallic conidiogenesis, and hyphal tips with hyphal vesicles within. The fruit bodies consist of large $(\sim 50-200 \mu \mathrm{m}$ in diameter) body-like structures with a defined outer membrane and an interior filled with calcite. The fruit bodies have at some stage been emptied of their contents of spores and filled by carbonate-forming fluids. A few fruit bodies not filled by calcite and with spores still within support this interpretation. Spore-like structures (ranging from a few $\mu \mathrm{m}$ to $\sim 20 \mu \mathrm{m}$ in diameter) are also observed outside of the fruit bodies and in some cases concentrated to openings in the membrane of the fruit bodies. The hyphae, fruit bodies and spores are all closely associated with a crust lining the vein walls that probably represent a mineralized biofilm. The results support a fungal presence in deep subseafloor basalts and indicate that such habitats were vital between $\sim 81$ and $48 \mathrm{Ma}$.
\end{abstract}

\section{Introduction}

The biosphere of the subseafloor basalts is with a few exceptions (Orcutt et al., 2010; Mason et al., 2010) known from the fossil record. The best known fossil structures are granular and tubular ichnofossils in volcanic glass (Furnes et al., 2008; Staudigel et al., 2008; McLoughlin et al., 2009). The production of such structures by biological dissolution has been extensively described in various reports (Thorseth et al., 1992, 1995; Staudigel et al., 2008; McLoughlin et al., 2009, 2010), but still today the microorganisms responsible for the production of these structures have not yet been found and characterized. Abiotic alternatives have been proposed, i.e. several authors have commented upon the resemblance between ichnofossils and ambient inclusion trails (AITs) (Staudigel et al., 2008; Walton, 2008), which is an abiotic process where a mineral grain is propelled through a substrate by elevated fluid pressure leaving a hollow tube behind. Lepot et al. (2009) described a process in which AITs in basalts were formed by chemical dissolution of quartz by migrating carbonaceous particles; thus, the formation of ichnofossils in volcanic glass is still debated.

Filamentous and coccoidal fossilized microorganisms have also been observed in subseafloor basalts (Schumann et al., 2004; Ivarsson et al., 2008a, b, 2009, 2012; Cavalazzi et al., 2011) and in ophiolites (Peckmann et al., 2008; Eickmann et al., 2009). Most fossilized microorganisms have been interpreted as remnants of prokaryotes, but Schumann et al. (2004) interpreted filamentous microfossils within carbonate vesicles in lava from the upper oceanic crust of the North Pacific as boring endolithic fungi, based on morphological characteristics including branching, septa, and central pores (Schumann et al., 2004). Ivarsson et al. (2012) reinterpreted fossilized microorganisms previously described as prokaryotes (Ivarsson et al., 2008a, b) as fossilized fungi based on morphological characteristics made visible by synchrotron-radiation X-ray tomographic microscopy (SRXTM) and the detection of chitin in cell walls by staining 
with the dye wheat germ agglutinin conjugated with fluorescein isothiocyanate (WGA-FITC).

Phylogenetic studies of dredged and shallowly drilled samples from the seafloor basalts support a prokaryotic dominance of mostly bacteria, but also of archaea (Thorseth et al., 2001; Lysnes et al., 2004; Santelli et al., 2008). However, this is simply due to exclusion of eukaryotes in the sequencing of samples from these depths. Connell et al. (2009) isolated and cultivated a diverse fungal community from basalt surfaces at hydrothermal vents and from cold surfaces that not had been hydrothermally altered at the Vailulu'u Seamount, Samoa. López-García et al. (2007) found eukaryotes including fungi in association with hydrothermal vents on the seafloor at Lost City hydrothermal field. Fungi have also been isolated from deep-sea sediments from the Japan Trench (4500-6500 m b.s.l.) (Abe et al., 2001), and yeasts and other fungi have been observed in deep-sea sediments from the Mariana Trench at $10897 \mathrm{~m}$ b.s.l. (Takami, 1999). Ivarsson et al. (2011) further reported of fossilised fungi from lithified volcaniclastic sediments from Gran Canaria in the Atlantic Ocean; thus, fungi is present in seafloor environments, but fungal presence in deep subseafloor basalts has only been reported once before (Ivarsson et al., 2012).

In this paper new findings associated with the fossilized fungi described by Ivarsson et al. (2012) are reported. Hyphal tips and additional morphological structures interpreted as reproductive structures have been studied, which indicate that the subseafloor fungi exist in vital colonies.

\subsection{Emperor Seamounts}

The submarine Emperor Seamount chain constitutes together with the Hawaiian Islands a continuous chain of volcanic seamounts and islands located at the center of the Pacific plate. The chain is considered to be the result of hotspot volcanism and extends over $5000 \mathrm{~km}$. The ages increase successively in a classical hotspot fashion to the northwest, away from the active hotspot. The youngest volcano that is related to Hawaiian volcanism today is Loihi Seamount which is in the process of active formation. The ages of Emperor Seamounts range from $\sim 81 \mathrm{Ma}$ to $43 \mathrm{Ma}$. From $\sim 43 \mathrm{Ma}$ to recent, the Hawaiian chain continues.

During the Ocean Drilling Program (ODP) Leg 197, four sites were drilled at three different seamounts: Detroit, Nintoku and Koko Seamounts. Sites 1203 and 1204 were drilled at a water depth of $2604.4 \mathrm{~m}$ at the summit of Detroit Seamount, one of the northernmost summits of the Emperor Seamounts. Site 1203 was drilled to a final depth of $914.6 \mathrm{~m}$ below seafloor (m b.s.f.). Site 1204 is made up of two drill holes, 1204A and 1204B, which were drilled to a total depth of 880.3 and $954.5 \mathrm{~m}$ b.s.f., respectively. Site 1205 was drilled on Nintoku Seamount at $1310 \mathrm{~m}$ of water depth with a final depth of $326.0 \mathrm{~m}$ b.s.f. Site 1206 was drilled on Koko Seamount at $1540 \mathrm{~m}$ of water depth with a final depth of $335.2 \mathrm{~m}$ b.s.f. A radiometric dating from ODP
Leg 145 (Site 884) has shown the age of Detroit Seamount to be $\sim 81 \mathrm{Ma}$. Nintoku Seamount has been dated at $56 \mathrm{Ma}$ and Koko Seamount at $48 \mathrm{Ma}$ which means that the samples in this study stretch over a total time period of $33 \mathrm{Ma}$.

\section{Samples and methods}

The samples used in this study were selected depending on the presence of fossilized fungi that correspond morphologically to the fungi described by Ivarsson et al. (2012). The sample used in Ivarsson et al. (2012) was also used. Eight samples were studied and are listed in Table 1. The samples range from all three seamounts and have a depth span between $\sim 44$ and $900 \mathrm{~m}$ b.s.f. The samples were prepared as doubly polished thin sections $(\sim 150-200 \mu \mathrm{m}$ in thickness) due to their advantages in the study of microfossils compared to ordinary thin sections ( $\sim 30 \mu \mathrm{m})$ (Ivarsson, 2006). The fossilized microorganisms were studied with optical microscopy and environmental scanning electron microscope (ESEM).

An XL30 environmental scanning electron microscope (ESEM) with a field emission gun (XL30 ESEM-FEG) was used to analyse the minerals and the fossilised fungal structures. The ESEM was equipped with an Oxford $\mathrm{x}$-act energy dispersive spectrometer (EDS), backscatter electron detector (BSE) and a secondary electron detector (SE). The acceleration voltage was 20 or $15 \mathrm{kV}$ depending on the nature of the sample, and the instrument was calibrated with a cobalt standard. Peak and element analyses were made using INCA Suite 4.11 software.

\section{Results}

\subsection{Crusts along the vein walls}

Fossilized hyphae either occur as dense, mycelium-like networks in veins and vesicles (Ivarsson et al., 2012) or as less complex assemblages associated with crusts along vein walls (Figs. 1, 2), which is the focus of this paper. Both types occur in association with each other and form coherent colonies. It appears as if the dense mycelium-like networks form in vesicles with limited space and that less dense assemblages occur in veins in between such vesicles.

The occurrence of fossilized hyphae in the crusts is usually less dense and distributed over larger areas, which makes it easier to find and study specific morphological characteristics. That might also be the reason why the variation of morphological structures appears to be greater than in the dense mycelium-like networks.

The crusts have an irregular shape and surface with spherical or sub-spherical structures of varied size $(\sim 10 \mu \mathrm{m}$ to $\sim 150 \mu \mathrm{m}$ in diameter) incorporated (Fig. 2). In transmitted light, these crusts appear as dark, reddish, partly opaque crusts (Fig. 2a, c), but in reflective light it is possible to see that they are composed by a mix of various phases (Fig. 2b, 

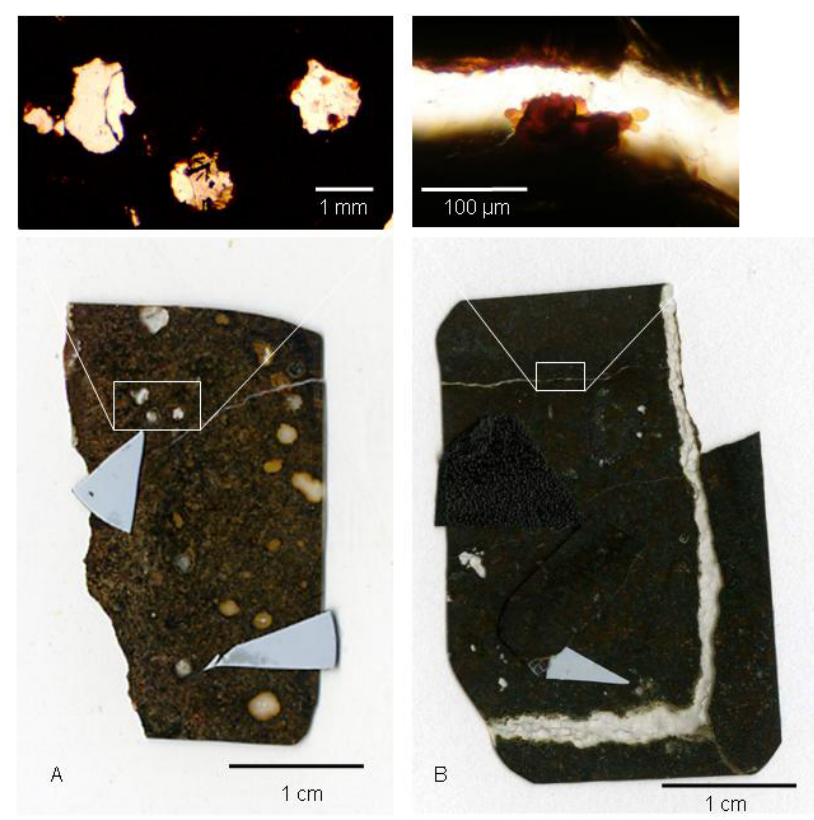

Fig. 1. Scanned thin sections for an overview. (A) 197-1205A-6R-2, 53. (B) 197-1203A-40R-5, 12.

Table 1. List of samples used in this study and corresponding depths.

\begin{tabular}{lr}
\hline Samples & Depth (m b.s.f.) \\
\hline 197-1203A-30R-1, 63 & 570.43 \\
197-1203A-40R-5, 12 & 661.22 \\
197-1203A-57R-3, 103 & 812.93 \\
197-1204B-12R-1, 24 & 906.54 \\
197-1205A-6R-2, 53 & 44.33 \\
197-1205A-19R-4, 48 & 114.53 \\
197-1206A-18R-1, 104 & 153.44 \\
197-1206A-37R-3, 72 & 295.13 \\
\hline
\end{tabular}

d). EDS analyses show that they consist of a mix of carbonates, iron oxides and components of $\mathrm{Si}, \mathrm{Al}, \mathrm{Fe}, \mathrm{Mg}$. In some cases the crusts are layered (Fig. 2e). The carbonates in the crusts are distinctly different both spatially and also in greyscale and crystal growth. Thus, they were not formed contemporaneously with the carbonates in the veins.

The crusts are associated with various spherical or subspherical body-like structures incorporated or associated with filamentous hyphae protruding in between (Figs. 2, 3, 4). There are a clear relationships between the hyphae and the larger, body-like structures. They are attached or interconnected in each other, and some of the larger, body-like structures are only attached to the crust by hyphae (Fig. 4).

It should be mentioned that the body-like structures are not only restricted to the crusts along the vein walls but occur in association with the dense mycelium-like networks as well; thus, there are no clear differences and it can merely be due
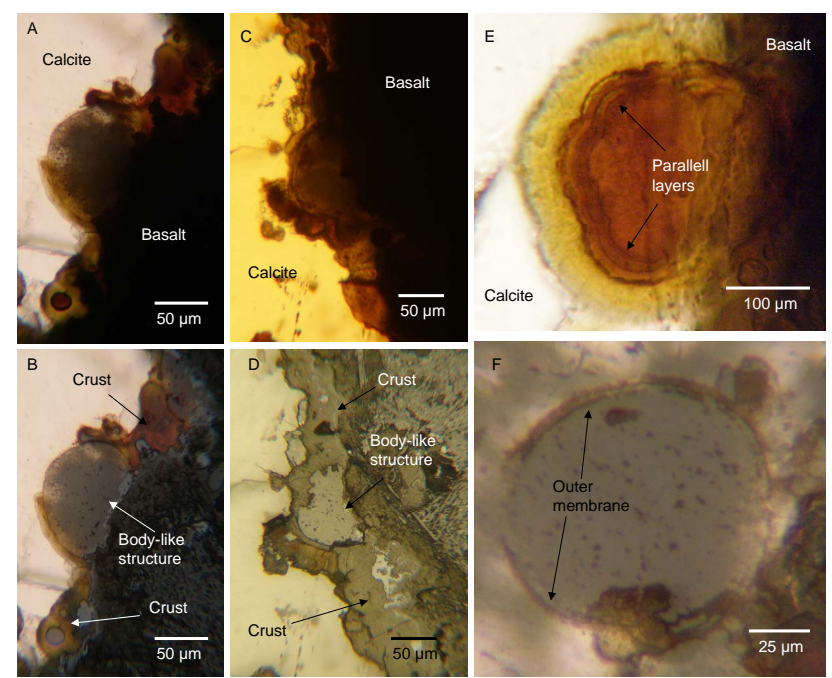

Fig. 2. Microphotographs of sample 197-1203A-40R-5, 12 (A, B, E), and sample 197-1204B-12R-1, 24 (C, D, F). (A) Image showing the crust at the interface between the basalt and the vein-filling calcite in transmitted light. Note the large body-like structure in the middle. (B) Same as (A) but in reflective light, which makes it possible to view the phases and structures within the crust. Note how the large body-like structure is filled with calcite that differs from the calcite in the vein. (C) Image showing the crust at the interface between the basalt and the vein-filling calcite in transmitted light. Note the large body-like structure. (D) The same as (C) but in reflective light. Note the calcite phase in the body-like structure and how it differs in comparison to the calcite of the vein. (E) Image showing an irregular structure within the crust with parallel layers. (F) Image showing a body-like structure with a defined outer membrane and an interior filled with carbonate.

to visibility that the body-like structures are better seen in the less dense areas.

\subsection{Fossilized hyphae}

Fossilized hyphae associated with the crusts do not normally form complex mycelium-like networks but occur less frequently and with less branching and rarely anastomosis between branches (Fig. 3). The less dense networks ease the study of single hypha and specific morphological characteristics in optical microscopy. Most hyphae are rather short ( $\sim 50$ to $100 \mu \mathrm{m}$ in length), compared to the hyphae that occur in the mycelium-like networks, and occur perpendicular to the surfaces of the crusts (Figs. 3, 4d, e). Due to the limited length of the hyphae and the absence of complex networks, hyphal tips have for the first time been observed and studied in the samples from the Emperor Seamounts. The hyphal tips are very well preserved and display a varied internal morphology. Septa (Fig. 3c) and hyphal walls (Fig. 3c, d, e) are very well preserved and displayed in the samples. Some of the hyphal tips show a terminal swelling demarcated by a septum. In some hyphae, numerous micro-sized structures 


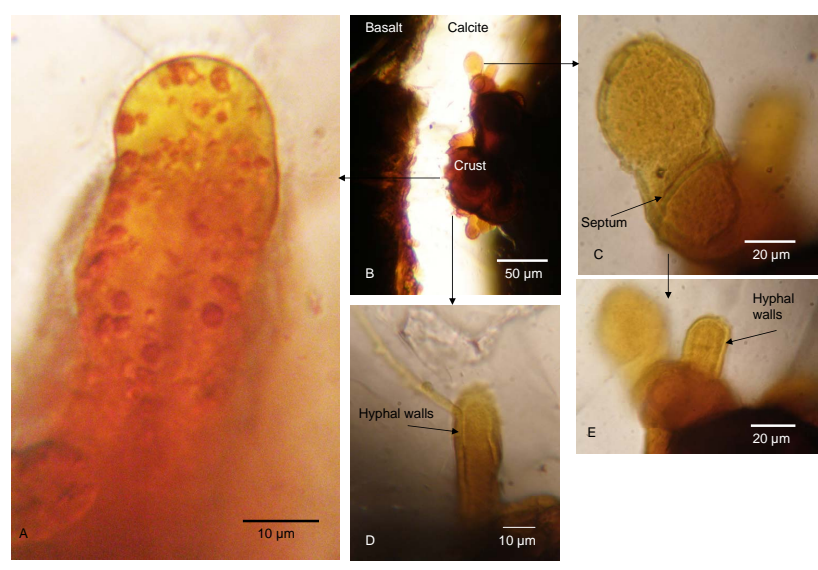

Fig. 3. Microphotographs of sample 197-1203A-40R-5, 12. (A) Image showing a well-preserved hyphal tip with abundant micro-sized bodies (hyphal vesicles) within. (B) Image showing an overview of the vein and the area of the crust that contains the filamentous hyphae. (C) Image showing a swollen hyphal tip and a well-preserved septum. (D) Hyphal tip with well-preserved hyphal walls. (E) Same as (C) but with a different focal depth showing a hyphal tip with well-preserved hyphal walls.

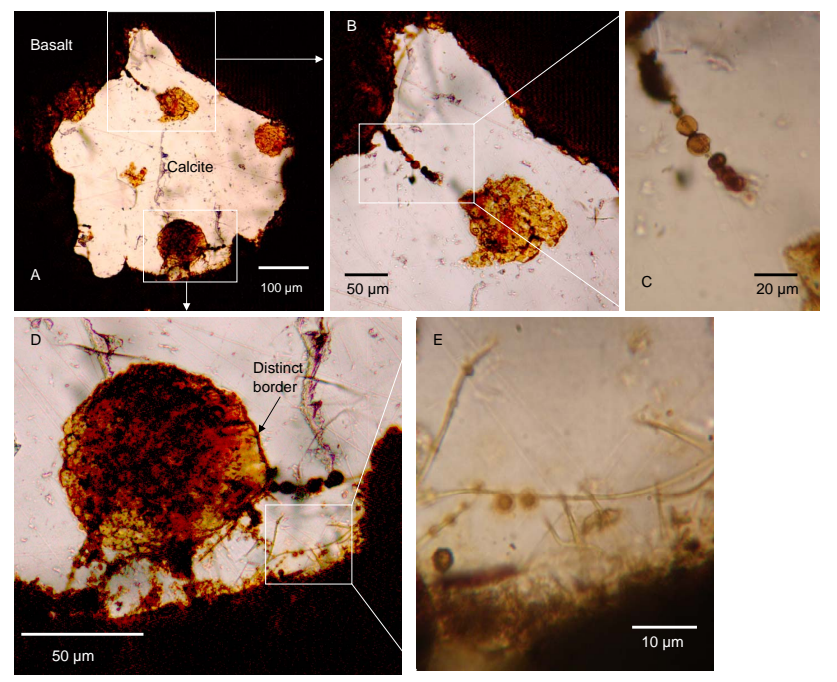

Fig. 4. Microphotographs of sample 197-1205A-6R-2, 53. (A) An overview of a vesicle in basalt filled with secondary calcite containing enclosed fossilized body-like structures and hyphae. (B) Closeup of a body-like structure that is attached to the vesicle wall by only hyphae. (C) Close-up of a hyphae with small spherical structures that resemble a "chain of pearls". (D) Large body-like structure attached to the vesicle wall with only hyphae. The body-like structure has a distinct border and an irregular surface that appears bulgy on the left side. The body-like structure is highly associated with hyphae and smaller spherical structures, especially in the area in between the body-like structure and the vesicle wall. (E) Close-up of hyphae in the area in between the body-like structure in (D) and the vesicle wall. Note that the hyphae are associated with smaller spherical structures. are concentrated at the front of the hyphal tips (Fig. 3a). The sizes of these structures are between $\sim 1$ and $3 \mu \mathrm{m}$ in diameter.

There are also hyphae of considerable length that reach up to $1 \mathrm{~mm}$ in length and deviate from the perpendicular direction of the shorter ones. They have more of an undulating appearance (Fig. 4b-e) and occur as runners sometimes parallel to the vein walls. Those longer hyphae are also normally associated with larger body-like structures and appear to anchor them to the vein walls. In a few cases, small spherical structures occur along the hyphae with the appearance of a "chain of pearls" (Fig. 3c).

\subsection{Large body-like structures}

Many fossilized hyphae and the crusts along the vein walls are associated with large spherical or sub-spherical structures, $\sim 50-200 \mu \mathrm{m}$ in diameter (Figs. 2a-d, f, 4a, b, d, 5a). These large structures or bodies are either directly related to the crusts of the vein walls or loosely attached to the walls by hyphae. The body-like structures are characterized by a distinct border that defines the spherical morphology of the structures (Figs. 2b, 4d, 5a). These borders are a few $\mu \mathrm{m}$ : s thick and enclose the interior of the spherical structures, resembling an outer membrane or a skin. The surfaces of these membranes are not perfectly smooth but irregular and sometimes bulgy (Fig. 4b, d). EDS analyses showed that the membranes of the body-like structures consist of a mix of $\mathrm{Fe}, \mathrm{C}$, $\mathrm{Ca}$ and $\mathrm{O}$ with contributions of $\mathrm{Si}, \mathrm{Al}, \mathrm{Mg}, \mathrm{Ti}, \mathrm{Mn}$ and $\mathrm{Cl}$. The $\mathrm{C}$ content is rather high, sometimes over $20 \mathrm{wt} \%$ (Fig. 5, Table 2).

The interiors of the body-like structures are dense, and no particular morphological characteristics can be observed. EDS analyses show that the interiors of the structures mostly consist of calcite (Fig. 5, Table 2); however, ESEM images and optical microscopy show that the calcite of the spherical structures is spatially separate from the vein-filling calcite and varies in greyscale (Figs. 2a-d, f, 5a). The variation in greyscale and coloration is probably due to different crystallinity as a result of different crystal growth in the body-like structures compared to the veins. Thus, it is most likely that the two various calcites represent different generations of calcite. The mineral succession in the veins suggests that the calcite in the body-like structures formed prior to the vein-filling calcite. The formation of calcite within the outer borders of the body-like structures further indicates that the body-like structures must have been hollow. If they at some stage had a content of some sort, they were emptied before the calcite formed. Most spherical structures also have an opening in their membrane, just as they were punctuated or split open from a pressure within (Fig. 2a-d, f). This pressure release occurred prior to the formation of the calcite and resulted in an opening in which calcite-forming fluids entered the structure. 
Table 2. EDS data related to Fig. 5.

\begin{tabular}{|c|c|c|c|c|c|c|c|c|c|c|}
\hline & Spectrum 1 & Spectrum 2 & Spectrum 3 & Spectrum 4 & Spectrum 5 & Spectrum 6 & Spectrum 7 & Spectrum 8 & Spectrum 9 & Spectrum 10 \\
\hline $\mathrm{C}$ & 14.95 & 15.22 & 17.21 & 24.01 & 19.97 & 11.09 & 14.79 & 15.99 & 10.32 & 12.50 \\
\hline $\mathrm{O}$ & 54.41 & 54.54 & 44.77 & 38.19 & 39.79 & 39.22 & 42.38 & 41.95 & 45.38 & 46.86 \\
\hline $\mathrm{Mg}$ & 0.67 & 0.22 & 0.77 & 0.55 & 0.74 & 0.94 & 0.76 & 0.81 & 1.09 & 0.78 \\
\hline $\mathrm{Na}$ & & 0.36 & & & & & & & & \\
\hline $\mathrm{Al}$ & 0.13 & 0.12 & 0.97 & 0.49 & 1.24 & 1.33 & 1.16 & 1.01 & 1.31 & 0.75 \\
\hline $\mathrm{Si}$ & 0.24 & 0.31 & 2.55 & 1.29 & 3.19 & 3.81 & 2.72 & 2.68 & 3.15 & 1.50 \\
\hline $\mathrm{Cl}$ & & & 0.66 & 0.65 & 1.12 & 1.07 & 0.69 & 0.80 & 0.64 & \\
\hline $\mathrm{Ca}$ & 29.60 & 29.23 & 7.61 & 21.05 & 5.70 & 4.41 & 7.96 & 7.46 & 4.76 & 21.50 \\
\hline $\mathrm{Ti}$ & & & 1.81 & 1.43 & 2.54 & 2.93 & 1.66 & 1.38 & 2.17 & 0.77 \\
\hline $\mathrm{Mn}$ & & & 1.38 & 1.65 & 2.19 & 2.03 & 0.91 & 0.88 & 1.14 & \\
\hline $\mathrm{Fe}$ & & & 22.26 & 3.64 & 23.53 & 33.17 & 26.98 & 27.05 & 30.04 & 15.35 \\
\hline Total & 100.00 & 100.00 & 100.00 & 100.00 & 100.00 & 100.00 & 100.00 & 100.00 & 100.00 & 100.00 \\
\hline
\end{tabular}
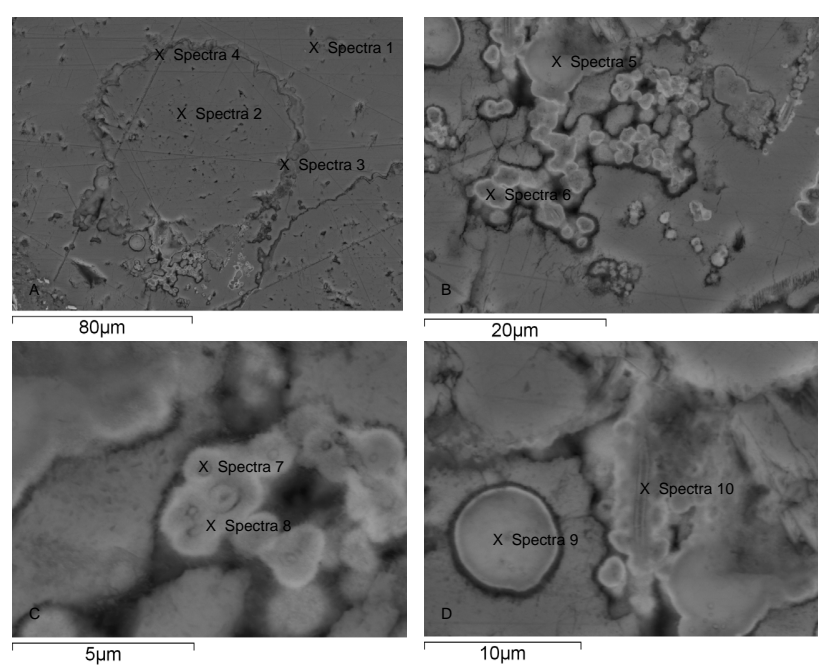

Fig. 5. ESEM images of the same large body-like structures as in Fig. 4 (A), (D), (E) (sample 197-1205A-6R-2, 53. (A) Cross section of the large body-like structure showing the distinct outer membrane and the in-filling of calcite. See Table 2 for EDS analysis. The membrane appears to have an opening at the bottom of the image where several small body-like structures occur just outside preserved in the calcite. (B) Close-up of the small body-like structures just outside the opening in the membrane of the large bodylike structure. (C) Close-up of the small body-like structure in (B). Note the inner core and the coating that almost is fuzzy in appearance. (D) A small spherical structure with a bottle-neck appearance.

There are a few exceptions where the structures do not have an opening in their outer membrane, where the structures have not been filled by calcite and where the structures are filled with minor body-like structures (Fig. 6). The minor structures within appear to be spherical or oval in shape and a few $\mu \mathrm{m}$ in diameter. However, they are relatively densely packed so it is difficult to observe any further morphology of these structures.
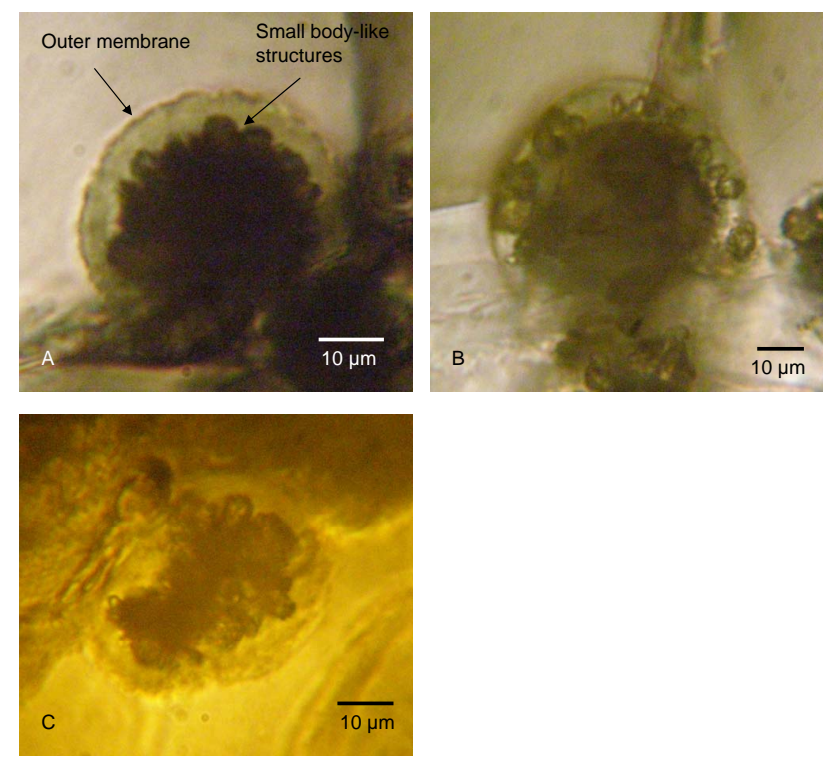

Fig. 6. Microphotographs of sample 197-1203A-40R-5, 12 (A), 197-1205A-6R-2, 53 (B), and 197-1206A-37R-3, 72, showing three different large body-like structures with intact membrane, no infilling of calcite and with small body-like structures still within the structures.

\subsection{Small body-like structures}

Apart from the small structures within the large body-like structures, there are small, spherical body-like structures, frequently occurring in the samples. They range from a few $\mu \mathrm{m}: \mathrm{s}$ to $\sim 20 \mu \mathrm{m}$ in diameter (Figs. $4 \mathrm{e}, 5,6,7$ ). These small structures occur in association with both fossilized hyphae, the large body-like structures and alone. Their morphology varies quite a bit. The smallest structures usually consist of an inner solid core and a coating that sometimes appear less dense and even fuzzy (Figs. 4e, 5b, c). The larger ones are more homogenous with no recognizable inner morphology. Their exterior is also quite smooth. Some even appear to have a hint of a bottle-neck (Fig. 5d). One substantial 

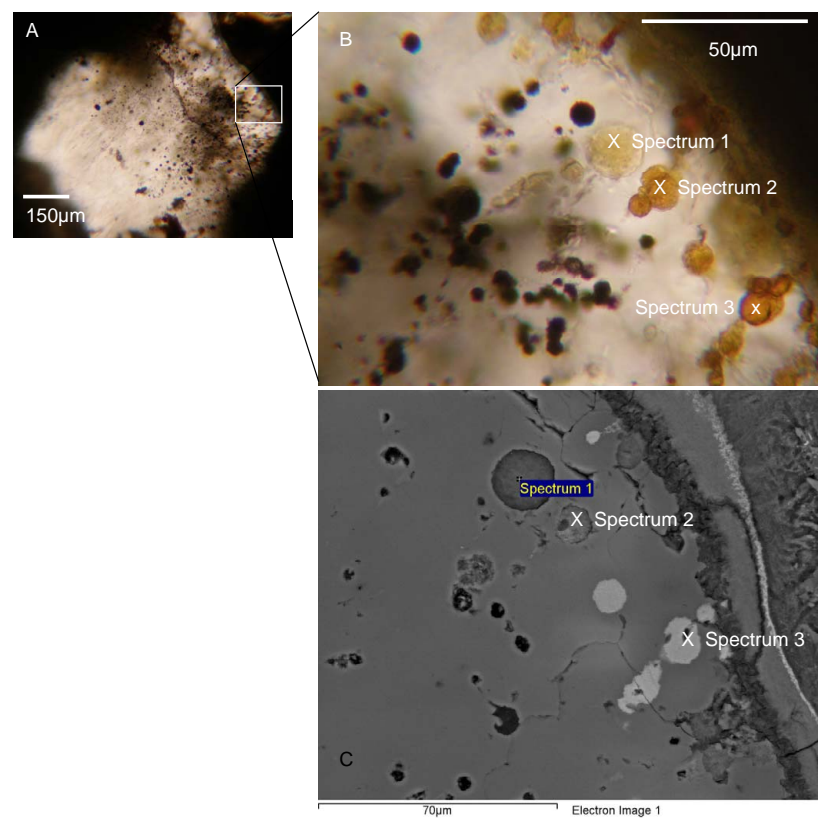

Fig. 7. Sample 197-1203A-40R-5, 12. (A) Microphotograph. An overview of a calcite filled vesicle in basalt. (B) Microphotograph. Close-up of small body-like structures close to the vesicle wall. (C) ESEM image of the same area as in (B). See Table 3 for corresponding EDS analysis.

Table 3. EDS data related to Fig. 7.

\begin{tabular}{lrrr}
\hline & Spectrum 1 & Spectrum 2 & Spectrum 3 \\
\hline $\mathrm{C}$ & 8.67 & 11.19 & 6.59 \\
$\mathrm{Mg}$ & 8.30 & 1.53 & 2.14 \\
$\mathrm{Al}$ & 3.46 & 0.71 & 2.50 \\
$\mathrm{Si}$ & 13.73 & 1.90 & 5.37 \\
$\mathrm{P}$ & & 0.44 & \\
$\mathrm{Ca}$ & 3.39 & 28.28 & 3.91 \\
$\mathrm{Mn}$ & & 6.65 & \\
$\mathrm{Fe}$ & 9.68 & 1.32 & 35.41 \\
$\mathrm{O}$ & 52.78 & 47.98 & 44.08 \\
\hline Total & 100.00 & 100.00 & 100.00 \\
\hline
\end{tabular}

difference between the small and the large body-like structures, described in the section above, is that the first has never been hollow and later filled with carbonates as the latter. The composition of the small structures is homogenous through the structure and usually characterized by a high $\mathrm{Fe}, \mathrm{C}$ and $\mathrm{O}$ content and with minor amounts of $\mathrm{Si}$, $\mathrm{Al}, \mathrm{Mg}, \mathrm{Ca}$. Some even contain low amounts of P (Table 3). The size of the small body-like structures corresponds to the size of the small structures within the larger body-like structures (Fig. 6). In some cases there is a concentration of small body-like structures at the openings of the large body-like structures (Fig. 5), like they have been discharged from the large body-like structures.

\section{Discussion}

\subsection{Fossilized hyphae}

The morphology of the hyphal tips corresponds well to the smooth, slightly snub-nosed shape of fungal hyphal tips. The hyphae walls are well preserved, and septa are in some hyphae highly pronounced. In Fig. 3c a swelling of the hyphal tip is seen which corresponds to the appearance of thallic conidiogenesis (Webster and Weber, 2007). This is a process in which terminal cells in a hypha become cut off by septa and converted into a conidium. This conidium is later released by the formation of a new conidium beneath. However, most remarkable with the fossilized hyphae is the small micro-sized structures preserved at the hyphal tip. The size, distribution and localisation of these micro-sized structures correspond to hyphae vesicles typically found at the hyphal tip. Hyphae vesicles are organelles derived from the Golgi apparatus and accumulate at the tip of the hyphae where they fuse and stimulate growth of the fungal hyphae. All growth in fungal hyphae occurs at the tip by this process. There are various types of organelles concentrated at the hyphae apex with varying size and morphology. The appearances of the microsized structures in the samples vary somewhat, which can be due to various organelles preserved or a result of shrinkage. Thus, distinguishing between various organelles is not possible at this stage.

The restricted length of the hyphae, the perpendicular appearance with respect to the surfaces of the crusts and the occurrence of hyphal tips suggest that the hyphae were in the initial stages of growth at the time of fossilization and that they originated from the crust.

\subsection{Reproductive structures}

Interpreting fossilized material is always an issue and urge cautiousness (e.g. Buick, 1991; Gibson et al., 2001; Ivarsson, 2006). Abiotic mineral structures are known to mimic microbial morphology, which has to be taken into consideration when interpreting putative fossilized microorganisms (Garcia-Ruiz et al., 2003). Typical microbial morphology is usually characterized by filaments or coccoids; thus, the morphology and appearance of the body-like structures described in this paper are rather deviant and perhaps controversial, which makes it more challenging to prove their potential biogenic origin. They could at a first glance easily be mistaken or explained as abiotic colloidal or nodular iron oxides or perhaps amorphous clay phases. Their localisation at the interface between the basalt and the vein, which at some point were circulated by fluids, could support an argument that they only are alteration products of fluid-rock interactions. However, the interface between the rock and the fluid filled vein is also the most attractive environment for microorganisms to colonize (Edwards et al., 2005), and, since their appearance and intriguing morphology suggest 
a biogenic origin, it is worth testing this. The arguments in favour of a biogenic origin of these microfossils are (1) geological context compatible with life and syngenicity with the rock, (2) close association with known fossilized microorganisms, (3) microbial morphology, and (4) the composition.

1. Subseafloor basalts are today established as microbial habitats (e.g. Thorseth et al., 2001; Furnes et al., 2008; Orcutt et al. 2010; Mason et al., 2010), and biogenicity of filamentous fossilized microorganisms interpreted as fungal hyphae has been reported from these exact samples (Ivarsson et al., 2008a, b, 2009, 2012). Thus, the geologic context is compatible with microbial life. The structures are indigenous with the rock and syngenetic with the secondary mineralisations in the sense that they have been entombed by the secondary carbonates. Thus, they existed in the fractures prior to the formation of the vein-filling calcite. They are seen in petrographic thin sections and were cut by the preparation of those; thus, they are not modern contaminants.

2 . The body-like structures are closely associated with filamentous microfossils previously interpreted as fossilized fungal hyphae, whose biogenicity has been discussed and established in several previous papers (Ivarsson et al., 2008a, b; 2009; 2012). Merely close association with known fossilized microorganisms is perhaps not a solid argument. However, it is a strong indication that they are related to microbial habitats, and this argument can be used together with other indications of biogenicity to build a firm case. Besides, the bodylike structures exist exclusively in association with fossilized hyphae and display not only nearness but a complex relationship and high involvement in the fungal mycelia. The structures also have a distinct morphology rather than a random resemblance with each other; thus, it is highly likely that the body-like structures represent more than trapped minerals or precipitation of mineral phases in a biofilm.

3. At a first glance in the microscope, the body-like structures can be mistaken for colloidal or nodular iron oxides or amorphous alteration products from fluid-rock interactions. Thus, there is a need to emphasize the microbiological characteristics of these structures. Colloidal iron oxides in subseafloor environments are associated with redox environments where iron-oxidising microorganisms are frequent; thus, colloidal iron oxides are usually closely associated with iron-oxidising microorganisms or structural remains of such, like stalks of Gallionella sp., for example (Boyd and Scott, 2001; Emerson and Moyer, 2002; Edwards et al., 2004). Besides, microbially mediated iron-oxidising reactions usually result in colloidal or amorphous iron oxides. Another factor that complicates things even further is that colloidal iron oxides usually are associated with organic and humic substances adsorbed on their surfaces (Perret et al., 2000). It is thus difficult to distinguish between biotically or abiotically formed colloidal iron oxides. However, abiotic particulate or colloidal iron oxides are always of nanosize and rarely exceed micro-size (Raiswell and Canfield, 2012). Colloidal iron oxides are also solid structures like col- loidal hematite. Usually they form from aggregation of nanoparticulate iron oxides or from concentric growth around a nucleus. The latter usually consists of concentric laminae.

The internal morphology of the large body-like structures described in this paper is the opposite of colloidal iron oxides. They are not solid colloids but consist of merely an outer, thin membrane. The rest of the body is filled by calcite. The calcite in-filling represents a different calcite generation than the vein-filling calcite which indicates that the structures were hollow prior to the calcite formation. The membrane that encloses the structures indicates that they were autonomous structures, well-defined from the surrounding environment. Their sub-spherical shape suggests that they initially must have had some content. Otherwise, they would have shrunk due to the hydrostatic pressure of the fluid filled veins. Most structures also have an opening in their membranes where the calcite-forming fluids probably entered. These openings suggest that these structures could have had a content but were emptied at some point. The few large bodylike structures that still have an intact membrane, not been filled by calcite and have a content of minor body-like structures inside, support such a theory. They probably represent the initial stage of the large body-like structures prior to emptying.

Not many microbial structures correspond to such morphology but fruit bodies (Deacon, 1997; Smith and Read, 1997; Ehrlich, 2002; Webster and Weber, 2007). Most fungi produce fruit bodies in which spores are contained. Ascomycetes, also called sac fungi, produce a fruit body that resembles a sac in which spores are contained. When the spores have been released, only the skin of an empty sac remains. An intriguing circumstance is that Ivarsson et al. (2012) interpreted the fossilized fungi in the samples from the Emperor Seamounts, based on morphological features, as Ascomycetes.. The structures described in this paper strongly resemble asci (fruit bodies of Ascomycetes) (Webster and Weber, 2007; Kang et al., 2010) of live Ascomycetes, not least from freshwater and marine living Ascomycetes (Kohlmeyer, 2010; Raja et al., 2010). The spheroidal shape and attachment to a surface by hyphae is similar to the occurrence of aquatic living Ascomycetes. Asci are also known from the fossil record to become well preserved (Taylor et al., 1999, 2005). The body-like structures in Fig. 6, which still have their content, probably represent fruit bodies that were not emptied before fossilisation and that still contain spores.

The size and the more homogenous interior of the small body-like structures suggest that they represent something else other than fruit bodies. However, their morphology as well as their close association with the larger body-like structures and the fossilized hyphae suggests that they represent a biological structure as well. The spherical and oval shape with a very well-defined inner core embedded in a coating corresponds in many ways to the shape and morphology of spores and excludes the possibility of coccoidal bacteria 
(Deacon, 1997; Smith and Read, 1997; Ehrlich, 2002; Webster and Weber, 2007). The size further supports such an interpretation even though size is not a reliable argument to distinguish between prokaryotes and eukaryotes (Schulz and Jørgensen, 2001). The coating that is visible in Figs. 4e and $5 \mathrm{~b}-\mathrm{d}$ may be a mucilaginous sheath, which is common among marine Ascomycetes. This hyaline layer swells in contact with water to aid buoyancy and attachment (Inderbitzin et al., 2002; Webster and Weber, 2007).

The size is also in agreement in relation to the suggested fruit bodies. In Fig. 5 it appears as if the small body-like structures have been released from the larger body-like structure. There appears to be an opening in the membrane of the large structure and small body-like structures occur just outside this ruptured area in abundance, just as spores that have been released from a fruit body.

The bottle-neck appearance of some small body-like structures is similar to conidium and could represent the released conidium discussed in the previous section on fossilised hyphae and shown in Fig. 3c.

4. Most body-like structures described in this paper have relative high amounts of $\mathrm{C}$ (Tables 2, 3), and the atomic ratios of $\mathrm{C}$ to $\mathrm{Mg}+\mathrm{Fe}+\mathrm{Ca}$ are not equal to unity, which suggests that some of the $\mathrm{C}$ is not in a carbonate phase. This does not necessarily mean that the $\mathrm{C}$ is biological in origin. However, it is important to note that the chemical composition of the outer membranes of the larger body-like structures and the composition of the smaller body-like structures correspond to the composition of the fossilized hyphal fungi previously described in these samples (Ivarsson et al., 2008a, b, 2009, 2012). It is a Fe, Si, Al, C-mix with minor amounts of $\mathrm{Ca}, \mathrm{Mg}, \mathrm{Ti}, \mathrm{Mn}$. The detection of $\mathrm{P}$ in the smaller bodylike structures is also interesting since $\mathrm{P}$ is a relevant element in biology and sometimes used as an indication of biological remnants in fossilized material (Giovannoni et al., 1996; Furnes and Muehlenbachs, 2003). It is also interesting since phosphate was detected by ToF-SIMS in the filamentous microfossils in samples from the Emperor Seamounts (Ivarsson et al., 2008a). The Si, Al, Fe (and C)-mix that fossilized microorganisms usually consist of has not been mineralogically identified but suggested to be a poorly crystallised clay phase (Ivarsson et al., 2008a).

The presence of clays as the main constituent of the fossilized material urges cautiousness since clays effectively adsorb elements, not least organic molecules. Potential ex-situ sources for $\mathrm{C}$ could be hydrothermal fluids or contamination during sample handling or preparation. However, previous EDS analyses of clays, palagonite, iron oxides and various amorphous phases not associated with microfossils in these samples have shown no or negligible amounts of $\mathrm{C}$ (Ivarsson and Holm, 2008; Ivarsson et al., 2008a, b, c). C has only been detected in structures that have been interpreted morphologically as biological remains such as fossilized hyphae or the outer membranes of the larger body-like structures discussed in this paper. Considering this restricted distribution of $\mathrm{C}$, it is most likely that $\mathrm{C}$ represents decomposed remains of the actual microorganisms, and not carbon molecules adsorbed by the clay phases.

\subsection{The crust}

Abiotic alteration of basalt or volcanic glass in contact with seawater produces a brown-yellowish gel-like material called palagonite. Palagonitization of basalt results in successive leaching, alteration and finally formation of authigenic minerals like clays and zeolites, which is seen as parallel alteration rims along the surfaces of veins, vesicles or shards of volcanic glass (Walton et al., 2005). The crust described in this paper does not correspond to the mineral succession and composition of palagonite but is more of a mix of carbonates, clays and iron oxides with body-like structures and fossilized hyphae incorporated resulting in a more bulgy and irregular appearance in comparison to the strictly parallel alteration rims of palagonite (Staudigel et al., 2008). The crust appears to have precipitated or to have grown on the vein walls rather than representing alteration stages. Thus, it corresponds more to a coating of the vein walls than rims produced by the alteration of the walls.

Most microorganisms, including fungi, produce biofilms by the excretion of extracellular polymeric substances (EPS). Fungal production of extracellular mucilaginous substances stimulates accumulation of inorganic compounds and subsequent precipitation of clay-like phases or oxides. If a considerable amount of inorganic material is deposited, decomposition of the fungus can be inhibited and fossilisation and preservation be stimulated (Gorbushina et al., 2002). Fungi in subaerial rock environments like hot and cold deserts with varying extremes in microclimatic conditions including irradiation, salinity, $\mathrm{pH}$, humidity and temperatures protect themselves by producing EPS and/or mucilaginous polysaccharides (Gorbushina, 2003; Volkmann et al., 2003; Gadd, 2007). Whole colonies can at extreme conditions be embedded in such mucilaginous precipitates and over time mineralized and transformed into a coating or crust that resembles rock varnish (Gorbushina, 2003). Hydrothermal systems are not comparable to subaerial desert environments but are extreme in nature. Shifts in temperature, $\mathrm{pH}$ and toxicity can occur rapidly. It is a possibility that the fungi described in this study have been forced to protect themselves from environmental stress by producing EPS that stimulated precipitation and/or deposition of mineral phases that subsequently mineralized to a crust.

\subsection{Subseafloor fungal habitats}

The presence of growing hyphae, fruit bodies and spores in subseafloor basalts indicates that it is not just remains of marine fungi transported by downward fluids, but that they represent vital fungal colonies thriving at these depths. The various morphological structures described in this paper 
represent the necessary components in a sustainable fungal habitat (Webster and Weber, 2007). Production of fruit bodies and spores indicates that fungi reproduce and migrate in the fractures and vesicles within the basalt. Transportation of spores through the system is probably favoured by migrating fluids, but fungal spores can be dispersed over large areas by forcible ejection from reproductive structures. Ascospores can be dispersed from ascus by explosive discharges and travel long distances in air. There are of course spatial limitations to spore discharges in subseafloor basalts, but it is probable that spores can migrate relatively long distances through the system by only a thin film of fluids. This mechanism of dispersal and the fact that they have been found in samples from three individual seamounts geographically separated by hundreds of kilometres indicate that the subseafloor basalts may act as a widespread habitat for fungus. They are also found in samples that span over 33 million years; thus, they are not an isolated event in time. This forces some reconsideration on the ecology of the deep biosphere. Firstly, eukaryotes may be much more abundant than previously was believed. Secondly, based on experience from other environments where fungi exist in vital symbiosis with other microand macroorganisms, it is probable to assume that fungi live in symbiosis with at least prokaryotes in subseafloor environments. Thirdly, in terrestrial settings like soils, fungi are a powerful geobiological agent that promotes mineral weathering, biomineralization, decomposition of organic matter, production of organic and inorganic acids, siderophores and chelators. Fungi are responsible for large-scale biogeochemical cycling of elements, transformations of metals and mineral deterioration, and it is most likely that fungi are involved in similar processes and reactions in the subseafloor settings, which may have global consequences. The presence of fungi in subseafloor basalts is, at the moment, only known through a fossil record but the intriguing results, so far, stress that near future explorations and drilling projects should be devoted to collect and isolate live fungi species to better understand this concealed biosphere.

\section{Conclusions}

Various morphological structures associated with fossilized fungal mycelia in subseafloor basalts have been described and interpreted. Large body-like structures consisting of an outer membrane and an interior filled by calcite have been interpreted to represent fungal fruit bodies. These fruit bodies were at some stage emptied of their contents of spores through openings in the membrane, in which calcite-forming fluids entered and filled the structures as they appear today. A few fossilised fruit bodies, still intact with spore-like structures within, support this interpretation. Spore-like structures also occur outside of the suggested fruit bodies, sometimes near possible openings in the outer membrane of the fruit bodies. The fruit bodies and the spores are closely associated with fossilised hyphae of excellent preservation. They display well-defined hyphal walls, septa, thallic conidiogenesis and hyphal tips with preserved hyphal vesicles within. Fruit bodies, spores and hyphae all occur closely associated in crusts that line the walls of the veins in the basalts. The crusts probably represent mineralised biofilms that might have protected the fungal colonies from environmental stress. These results indicate that subseafloor basalts acted as fungal habitats during a period between 81 and $48 \mathrm{Ma}$ and probably still do. Thus, it is suggested that sampling of live species should be of highest priority in near future ocean drilling programs.

Acknowledgements. Marianne Ahlbom at the Department of Geological Sciences at the Stockholm University is thanked for the assistance with the ESEM analysis. This work was supported by the Swedish National Space Board.

Edited by: E. J. Javaux

\section{References}

Abe, F., Miura, T., Nagahama, T., Inoue, A., Usami, R., and Horikoshi, K.: Isolation of a highly copper-tolerant yeast, Cryptococcus sp. from the Japan Trench and the induction of superoxide dismutase activity by $\mathrm{Cu}^{2+}$, Biotechnol. Lett., 23, 20272034, 2001.

Boyd, T. D. and Scott, S. D.: Microbial and hydrothermal aspects of ferric oxyhydroxides and ferrosic hydroxides: the example of Franklin Seamount, Western Woodlark Basin, Papua New Guinea, Geochem. Trans., 2, 7, doi:10.1186/1467-4866-245, 2001.

Buick, R.: Microfossil recognition in Archean rocks: an appraisal of spheroids and filaments from a 3500 m.y. old chert-barite unit at North Pole, Western Australia, Palaios, 5, 441-459, 1991.

Cavalazzi, B., Westall, F., Cady, S. L., Barbieri, R., and Foucher, F.: Potential fossil endoliths in vesicular pillow basalt, Coral Patch Seamount, Eastern North Atlantic Ocean, Astrobiology, 11, 619632, 2011.

Connell, L., Barrett, A., Templeton, A., and Staudigel, H.: Fungal diversity associated with an active deep sea volcano: Vailulu'u Seamount, Samoa, Geomicrobiol. J., 26, 597-605, 2009.

Deacon, J. W.: Modern mycology, Wiley Blackwell, Oxford, p. 304, 1997.

Edwards, K. J., Bach, W., McCollom, T. M., and Rogers, D. R.: Neutrophilic iron-oxidizing bacteria in the ocean: their habitats, diversity, and roles in mineral deposition, rock alteration, and biomass production in the deep-sea, Geomicrobiol. J., 21, 393404, 2004.

Edwards, K. J., Bach, W., and McCollom, T. M.: Geomicrobiology on oceanography: microbe-mineral interactions at and below the seafloor, Trends. Microbiol., 13, 449-456, 2005.

Ehrlich, H. L.: Geomicrobiology, New York, Marcel Dekker, p. 768, 2002.

Eickmann, B., Bach, W., Kiel, S., Reitner, J., and Peckmann, J.: Evidence for cryptoendolithic life in Devonian pillow basalts of Variscan orogens, Germany, Palaeogeog. Palaeoclimatol. Palaeoecol., 283, 120-125, 2009. 
Emerson, D. and Moyer, C. L.: Neutrophilic Fe-oxidizing bacteria are abundant at the Loihi Seamount hydrothermal vents and play a major role in Fe oxide deposition, Appl. Environ. Microbiol., 68, 3085-3093, 2002.

Furnes, H. and Muehlenbachs, K.: Bioalteration recorded in ophiolitic pillow lavas, in: Special Publication 218: Ophiolites in Earth's History, edited by: Dilek, Y. and Robinson, P. T., Geological Society of London, London, 415-426, 2003.

Furnes, H., McLoughlin, N., Muehlenbachs, K., Banerjee, N., Staudigel, H., Dilek, Y., de Wit, M., Van Kranendonk, M., and Schiffman, P.: Oceanic pillow lavas and hyaloclastites as habitats for microbial life through time-A review, in: Links between geological processes, microbial activities and evolution of life, edited by: Dilek, Y., Furnes, H., and Muehlenbachs, K., Springer, 1-68, 2008.

Gadd, G. M.: Geomycology: biogeochemical transformations of rocks, minerals, metals and radionuclides by fungi, bioweathering and bioremediation, Mycol. Res., 111, 3-49, 2007.

Garcia-Ruiz, J. M., Hyde, S. T., Carnerup, A. M., Christy, A. G., Van Kranendonk, M. J., and Welham, N. J.: Self-assembled silica-carbonate structures and detection of ancient microfossils, Science, 416, 1194-1197, 2003.

Gibson, E. K., McKay, D. S., Thomas-Keptra, K. L., Wentworth, S. J., Westall, F., Steele, A., Romanek, C. S., Bell, M. S., and Toporski, J.: Life on Mars: evaluation of the evidence within Martian meteorites ALH84001, Nakhla, and Shergotty, Precambrian Res., 106, 15-34, 2001.

Giovannoni, S. J., Fisk, M. R., Mullins, T. D., and Furnes, H.: Genetic evidence for endolithic microbial life colonizing basaltic glass-seawater interfaces, in: Proceedings of the Ocean Drilling Program, Scientific Results, 148, Ocean Drilling Program, College Station, TX, 207-214, 1996.

Gorbushina, A.: Microcolonial fungi: survival potential of terrestrial vegetative structures, Astrobiology, 3, 543-554, 2003.

Gorbushina, A. A., Krumbein, W. E., and Volkmann, M.: Rock surfaces as life indicators: new ways to demonstrate life and traces of former life, Astrobiology, 2, 203-213, 2002.

Inderbitzin, P., Kohlmeyer, J., Volkmann-Kohlmeyer, B., and Berbee, M. L.: Decorospora, a new genus for the marine ascomycete Pleospora gaudefroyi, Mycologia, 94, 651-659, 2002.

Ivarsson, M.: Advantages of doubly polished thin sections for the study of microfossils in volcanic rock, Geochem. T., 7, 5, 2006.

Ivarsson, M. and Holm, N. G.: Microbial colonization of various habitable niches during alteration of oceanic crust, in: Links between Geological Processes, Microbial Activities and Evolution of Life, edited by: Dilek, Y., Furnes, H., and Muehlenbachs, K., Springer Publications, 69-111, 2008.

Ivarsson, M., Lausmaa, J., Lindblom, S., Broman, C., and Holm, N. G.: Fossilized microorganisms from the Emperor Seamounts: implications for the search for a sub-surface fossil record on Earth and Mars, Astrobiology, 8, 1139-1157, 2008a.

Ivarsson, M., Lindblom, S., Broman, C., and Holm, N. G.: Fossilized microorganisms associated with zeolite-carbonate interfaces in sub-seafloor hydrothermal environments, Geobiology, 6, 155-170, 2008b.

Ivarsson, M., Gehör, S., and Holm, N. G.: Micro-scale variations of iron isotopes in fossilized microorganisms, International Journal of Astrobiology, 7, 93-106, 2008c.
Ivarsson, M., Broman, C., Lindblom, S., and Holm, N. G.: Fluid inclusions as a tool to constrain the preservation conditions of subseafloor cryptoendoliths, Planet. Space Sci., 57, 477-490, 2009.

Ivarsson, M., Broman, C., Holmström, S. J. M., Ahlbom, M., Lindblom, S., and Holm, N. G.: Putative fossilised fungi in the lithified volcaniclastic apron of Gran Canaria, Spain Astrobiology, 11, 633-650, 2011.

Ivarsson, M., Bengtson, S., Belivanova, V., Stampanoni, M., Marone, F., and Tehler, A.: Fossilized fungi in subseafloor Eocene basalts, Geology, 40, 163-166, 2012.

Kang, H.-J., Sigler, L., Lee, J., Gibas, C. F. C., Yun, S.-H., and Lee, Y.-W.: Xylogone ganodermophtora sp. Nov., an ascomycetous pathogen causing yellow rot on cultivated mushroom Ganoderma lucidum in Korea, Mycologia, 102, 1167-1184, 2010.

Kohlmeyer, J.: Marine fungi (Ascomycetes) within and on tests of Foraminifera, Mar. Biol., 90, 147-149, 2010.

Lepot, K., Philippot, P., Benzerara, K., and Wang, G.-Y.: Garnetfilled trails associated with carbonaceous matter mimicking microbial filaments in Archean basalt, Geobiology, 7, 393-402, 2009.

López-García, P., Vereshchaka, A., and Moreira, D.: Eukaryotic diversity associated with carbonates and fluid-seawater interface in Lost-City hydrothermal field, Environ. Microbiol., 9, 546-554, 2007.

Lysnes, K., Thorseth, I. H., Steinsbau, B. O., Øvreås, L., Torsvik, T., and Pedersen, R. B.: Microbial community diversity in seafloor basalt from the Arctic spreading ridges, FEMS Microbiol. Ecol., 50, 213-230, 2004.

McLoughlin, N., Furnes, H., Banerjee, N. R., Muehlenbachs, K., Staudigel, H.: Ichnotaxonomy of microbial trace fossils in volcanic glass, J. Geol. Soc., 166, 159-169, 2009.

McLoughlin, N., Staudigel, H., Furnes, H., Eickmann, B., and Ivarsson, M.: Mechanisms of microtunneling in rock substrates: distinguishing endolithic biosignatures from abiotic microtunnels, Geobiology, 8, 245-255, 2010.

Mason, O. U., Nakagawa, T., Rosner, M., Van Nostrand, J. D., Zhou, J., Maruyama, A., Fisk, M. R., and Giovannoni, S. J.: First investigation of microbiology of the deepest layer of ocean crust, PLoSONE, 5, e15399, doi:10.1371/journal.pone.0015399, 2010.

Orcutt, B. N., Bach, W., Becker, K., Fisher, A. T., Hentscher, M., Toner, B. M., Wheat, C. G., and Edwards, K. J.: Colonization of subsurface microbial observatories deployed in young ocean crust, ISME J., 5, 692-703, 2010.

Peckmann, J., Bach, W., Behrens, K., and Reitner, J.: Putative cryptoendolithic life in Devonian pillow basalt, Rheinisches Schiefergebirge, Germany, Geobiology, 6, 125-135, 2008.

Perret, D., Gaillard, J.-F., Dominik, J., and Atteia, O.: The diversity of natural hydrous iron oxides, Environ. Sci. Technol., 34, 35403546, 2000.

Raiswell, R. and Canfield, D. E.: The iron biogeochemical cycle past and present, Geochem. Perspect., 1, 1-220, 2012.

Raja, H. A., Violi, H. A., and Shearer, C. A.: Freshwater ascomycetes: Alascospora evergladensis, a new genus and species from the Florida Everglades, Mycologia, 102, 33-38, 2010.

Santelli, C. M., Orcutt, B. N., Banning, E., Bach, W., Moyer, C. L., Sogin, M. L., Staudigel, H., and Edwards, K. J.: Abundance and diversity of microbial life in ocean crust, Nature, 453, 653-657, 2008. 
Schumann, G., Manz, W., Reitner, J., and Lustrino, M.: 2004, Ancient fungal life in North Pacific eocene oceanic crust, Geomicrobiol. J., 21, 241-246, 2004.

Schulz, H. N. and Jörgensen, B. B.: Big bacteria, Annu. Rev. Microbiol., 55, 105-137, 2001.

Smith, S. E. and Read, O. J.: Mycorrhiza symbiosis, Academic Press, London, 1997.

Staudigel, H., Furnes, H., McLoughlin, N., Banerjee, N. R., Connell, L. B., and Templeton, A.: 3.5 billion years of glass bioalteration: Volcanic rocks as a basis for microbial life?, Earth-Sci. Rev., 89, 156-176, 2008.

Takami, H.: Isolation and characterization of micro-organisms from deep-sea mud, in: Extremophiles in deep-sea environments, edited by: Horikoshi, K., and Tsujii, K., Springer-Verlag, Tokyo, 1999.

Taylor, T. N., Hass, H., and Kerp, H.: The oldest fossil ascomycetes, Nature, 399, p. 648, 1999.

Taylor, T. N., Hass, H., Kerp, H., Krings, M., and Hanlin, R. T.: Perithecial ascomycetes from the 400 million year old Rhynie chert: an example ofancestral polymorphism, Mycologia, 97, 269-285, 2005.

Thorseth, I. H., Furnes, H., and Heldal, M.: The importance of microbiological activity in the alteration of natural basaltic glass, Geochim. Cosmochim. Ac., 56, 845-850, 1992.
Thorseth, I. H., Furnes, H., and Tumyr, O.: Textural and chemical effects of bacterial activity on basaltic glass: an experimental approach, Chem. Geol., 119, 139-160, 1995.

Thorseth, I. H., Torsvik, T., Torsvik, V., Daae, F. L., Pedersen, R. B., and Keldysh-98 Scientific Party, Diversity of life in ocean floor basalt, Earth Planet. Sci. Lett., 194, 31-37, 2001.

Volkmann, M., Whitehead, K., Rutters, H., Rullkotter, J., and Gorbushina, A. A.: Mycosporine-glutamicol-glucoside: a natural uvabsorbing secondary metabolite of rock-inhabiting microcolonial fungi, Rapid Commun. Mass Sp., 17, 897-902, 2003.

Walton, A. W.: Microtubules in basaltic glass from Hawaii Scientific Drilling Project \#2 phase 1 core and Hilina slope, Hawaii: evidence of the occurrence and behaviour of endolithic microorganisms, Geobiology, 6, 351-364, 2008.

Walton, A. W., Schiffman, P., and Macpherson, G. L.: Alteration of hyaloclastites in the HSDP 2 Phase 1 Drill Core: 2 Mass balance of the conversion of sideromelane to palagonite and chabazite, Geochem. Geophys. Geosyst., 6, Q09G19, doi:10.1029/2004GC000903, 2005.

Webster, J. and Weber, R. W. S.: Introduction to fungi, Cambridge University Press, 3rd Edn., Cambridge, UK, p. 841, 2007. 